\title{
Strain Pattern Analysis of Mylonites From Sitampundi-Kanjamalai Shear Zone, Thiruchengode, South India
}

\author{
V. Thirukumaran a, ", T.K. Biswal b, K. Sundaralingam c, V. Sowmya a , S. Boopathi a , R. Mythili a, \\ a Department of Geology, Government Arts College, Salem 636 007, Tamil Nadu, India \\ b Department of Earth sciences, IIT Bombay, Poway, Mumbai, India. \\ c Department of Geological Survey of India, Hyderabad, India.
}

*Corresponding Author mailkumaran75@gmail.com (V. Thirukumaran)

Received : 21 03 2019 Accepted: 03 05 2019

\begin{abstract}
This study aims to investigate the petrography and strain pattern of mylonites from parts of $\mathrm{N} \sim \mathrm{S}$ trending Sitampundi Kanjamalai Shear Zone (SKSZ) around Thiruchengode. The petrographic study indicates the presence of recrystallized quartz, K feldspar, plagioclase, biotite and some hornblende. The kinematic analysis of Mylonites was done with the help of shear sense indicators such as recrystallized type quartz (quartz ribbon) around the cluster of feldspar, S C fabric shows dextral shear sense and some sinisterly shear sense in some parts of SASZ which can be considered as a product of partitioning of both strain and vorticity between domains. These all indicates the simple shear extension along $\mathrm{E} \sim \mathrm{W}$ direction and the mylonitic foliation shows the pure shear compression along $\mathrm{N} \sim \mathrm{S}$ direction. Further the study of bulk strain analysis by Flinn plot method using $\mathrm{L}$ and $\mathrm{T}$ section of mylonite shows $\mathrm{k}<1$ which lies in the field of flattening zone of finite strain. The kinematic vorticity number is calculated by Rxz/ $\beta$ method which gives the value of 0.36 indicating the general shear. The rigid grain graph shows that the pure shear component is more dominant than the simple shear component. The analysis leads to the conclusion that the mylonite has experienced a high temperature shearing of above $700^{\circ}$ at deep crustal level.
\end{abstract}

Keywords: Mylonite; SASZ; Strain pattern; Vorticity, Kinematic analysis. Pure shear, Bulk strain.

\section{Introduction}

Mylonitic rocks are foliated high strain rocks formed in ductile shear zones under low to medium grade metamorphic conditions [1, 2]. Mylonites are excellent primary sources for understanding the tectonic history of an area because they are relicts of past shear zones. These high strain rocks record the conditions and the movement direction(s) of the fault [2 4].

In the field, mylonites are subdivided into three categories by their matrix to porphyroclast ratio [1, 2]. Protomylonites contain up to $50 \%$ matrix by volume; mylonites contain 50 90\% matrix; and ultramylonites contain upwards of $90 \%$ matrix. It traditionally has been assumed that mylonite development was the progressive result of increasing ductile deformation with no change in deformation mechanisms [5]. These occurrences indicate that spatial variations in deformation mechanisms, rather than variations in strain intensity, may form different mylonitic rocks.

Mylonites forms at greater depth and temperature above $300^{\circ} \mathrm{c}$. They are common in thrusts, extensional shear zones and steep basement shear zones. The process of mylonitization is usually associated with addition of aqueous fluid to the deforming rock system.

Mylonites in high grade metamorphic rock, gives the evidences of retrogression, recrystallization and indicates a exhumed shear zone. An attempt here is made to study the petrology and strain pattern in mylonites of Sitampundi Kanjamalai Shear Zone (SKSZ) near Thiruchengode. The study area covers survey of India (SOI) topographic sheets $58 \mathrm{I} / 3,58 \mathrm{I} / 458 \mathrm{E} / 15$ and $58 \mathrm{E} / 16$. The samples have been collected from the area located between $11.23984 \mathrm{~N}$ to $11.440679 \mathrm{~N}$ latitude and $77.89286 \mathrm{E}$ to $77.988295 \mathrm{E}$ longitude of Thiruchengode, Namakkal. The outcrops of Mylonites can be traced near Morepalayam and near Unjanai. Fig. 1.

\section{Geological Setting}

Salem Attur Shear Zone (or Moyar Bhavani Salem Attur Shear Zone) together with Palaghat Cauveri Shear Zone form an important tectonic line in Southern Granulite Province. 


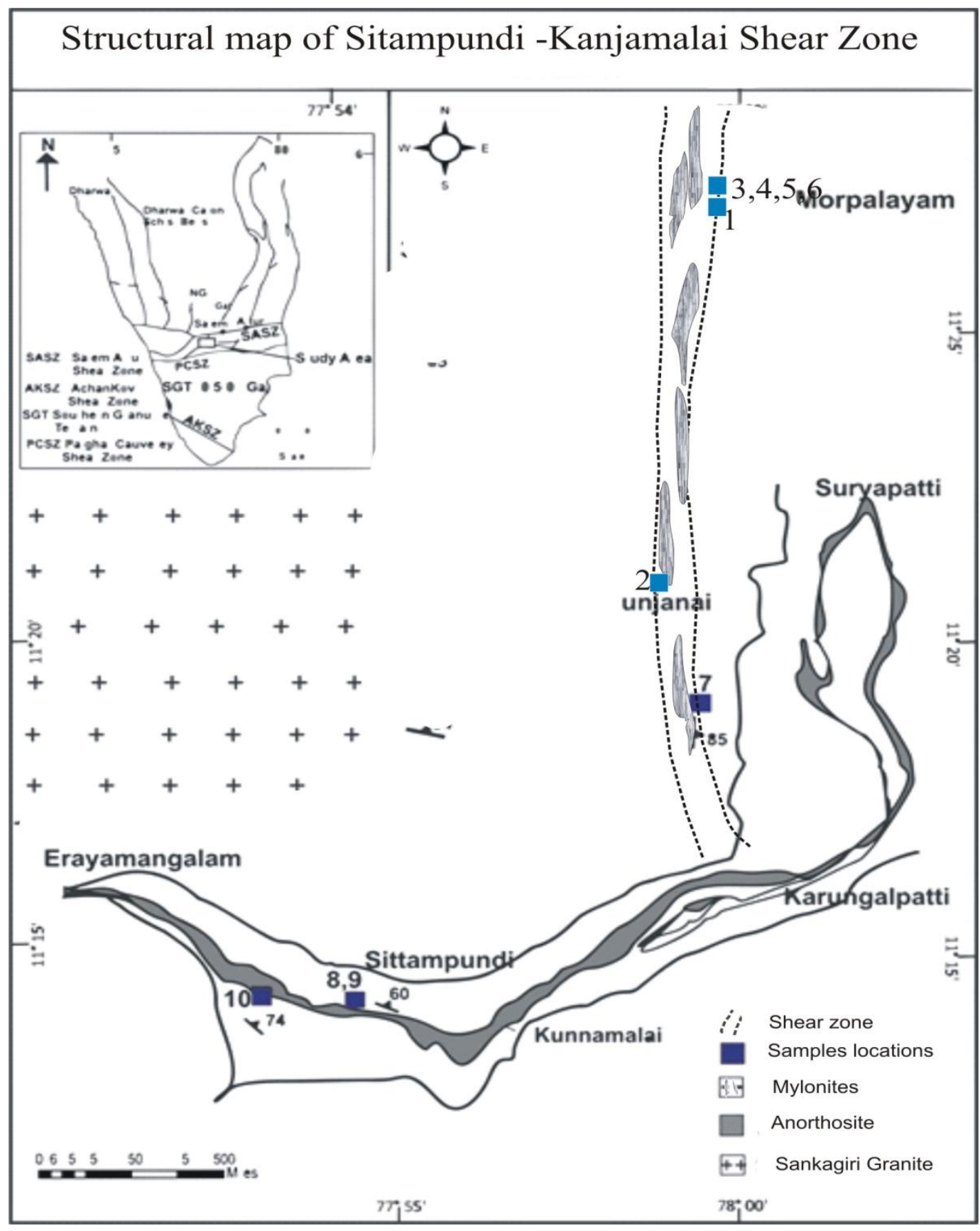

Fig1. Study area map

The zone runs in an $\mathrm{E} \sim \mathrm{W}$ direction and demarcates the Shear Zone registering predominant dip slip movements are suture between two geologically distinct terrane namely the responsible for exhumation or bringing up to the surface of northern (NGT) and the southern Granulite terrane (SGT or lower crustal charnockitic and granulitic rocks [8]. Pandiyan Mobile Belt) of Archean and neoproterozoic age Simultaneously there was dextral strike -slip displacement of respectively. The Southern terrane records an overall order of $70 \mathrm{~km}$ [9]. From Salem to MSZ there is a systematic clockwise $\mathrm{P} \sim \mathrm{T}$ path and displays domal structures. Both rotation of NNE $\sim \mathrm{SSW}$ oriented structures of the Late Archean terranes are juxtaposed along SASZ [6, 7]. The exact nature Niligiri-Pachamalai domain, implying large scale strike -slip of juxtaposition whether through thrusting or strike slip displacement under a transpressional regime [10]. shearing has been a matter of debate.

South of the Salem Attur shear zone (SASZ) to

ENE $\sim$ WSW trending SASZ forms a valley, $2 \sim 5 \mathrm{~km}$ Palghat Cauvery shear zone (PCSZ) is referred to as Salem wide and $100 \mathrm{~km}$ long, characterised by east - west structural Namakkal Subterrane. Seismic studies indicate a divergent trends between Salem and Attur. The faults of Moyar Attur reflection pattern at the boundary (with reflections dipping 
towards the boundary), suggesting a thicker crust $(\sim 46 \mathrm{~km})$ beneath the Salem Namakkal Subterrane, and a pattern of tectonically induced imbricate faulting in the lower crust and upper mantle of this region. These observations are indicative of a collisional environment in which the Salem Namakkal Subterrane was accreted in the mid Archaean. Clark et al., dated charnockitic rocks within the Salem subterrane to $2538 \pm 6 \mathrm{Ma}$ and $2529 \pm 7 \mathrm{Ma}$ (SHRIMP $\mathrm{Pb} \sim \mathrm{Pb})$. SHRIMP dated rims from the same zircons showed statistically distinct $2473 \pm 8 \mathrm{Ma}$ and 2482 \pm 15 Ma ages. Clark et al., have considered the Archaean ages crystallization ages for the charnockitic protolith and the younger ages as partial melting that occurred during the accretion. Most recently, Saitoh et al. 2010 have reported SHRIMP U Pb dating of zircon grains in HP charnockitic rock from Kanjamalai region and obtained mean $207 \mathrm{~Pb} / 206 \mathrm{~Pb}$ age of $2477.6 \pm 1.8$ and dated the two trondhjemite sample from Namakkal and reported the SHRIMP zircon $\mathrm{U} \sim \mathrm{Pb}$ dates of $2528 \pm 61$ and $2545 \pm 56 \mathrm{Ma}$ [11].

\section{Petrological Study}

Mafic granulite

The mafic granulites are grey in colour, fine to medium grained granulitic rock with typical 'salt and pepper' texture on weathered surface. It is medium grained, granoblastic and consists essentially of clinopyroxene, orthopyroxene, hornblende and biotite in various proportions with plagioclase and quartz. Apatite and ilmenite occurs as accessories. Pink garnets upto to $1 \mathrm{~mm}$ to $2 \mathrm{~mm}$ diameter is locally noticed and at some places large size garnets are observed in the rocks.

Mafic granulite consists of varied mineral assemblages occurred within very short distance. The assemblages are as follows;

1. Orthopyroxene + clinopyroxene + garnet + plagioclase

2. Orthopyroxene + garnet + plagioclase

3. Clinopyroxene + garnet + plagioclase

4. \pm orthopyroxene \pm clinopyroxene + biotite + hornblende + ilmenite + plagioclase

Under microscope the mafic granulite shows the development of hornblende. The development of hornblende and biotite are the result of retrogression during shearing and hornblendes are bluish tinge in color.

Hence the parent rock for these granulites may be the gabbro. One which is having orthopyroxene, clinopyroxene and shows equigranular grains with triple junction with different minerals may represent end stage of granulite metamorphism; hence, the original igneous texture is lost. The fourth mineral assemblage consists of bluish green hornblende with biotite. The garnet porphyroblast shows inclusions of quartz, biotite, and hornblende so this garnet may be late stage either synkinematic to post kinematic shearing and these garnets may use to determine P T calculation and that will be described later. At places the rock is extremely enriched with hornblende showing well developed foliation. However, elongated orthopryoxene are also present in it.

\section{Amphibolites}

The mafic granulite east of Sangakiri granite near Morpalayam shows extreme schistose character due to excess development of hornblendes. So, these outcrops have been identified as amphibolite. The amphibolite outcrop shows gentle dipping towards SE and down dip lineation with NNE SSW trend as observed in the NE periphery of the Sangakiri granite. Small scale outcrops are also observed near Namakkal as inter bands within the quartz feldspathic gneiss. The development of amphibole in the rock may be retrogression during shearing.

Under microscope, the amphibolites are well foliated and the rock shows medium to coarse grains of hornblende and plagioclase feldspar. The hornblende grains are oriented parallel to define the foliation in the rock, the plagioclase grains shows almost equidimensional shape. The plagioclase grains generally lack polysynthetic twining but they have prominent one set of cleavage. In the amphibolites relict opx grains are observed; this suggests that the amphibolites are developed from the retrogression of mafic granulites. Hornblendes are prismatic, green colour and are oriented parallel, and epidotes are also observed in the mineral assemblages.

Ambhibolite forms major rock unit in the area pervaded by granites and granitic gneiss. These rocks have been mylonitized and retrogressed to low grade schist, especially along the shear zone. Within the valley, the SASZ comprises anastomosing minor shear zone giving rise to a 1 to $1.5 \mathrm{~km}$ wide planar mylonite zone.

Hornblende biotite gneiss, quartz feldspathic gneiss and migmatites

Hornblende biotite gneiss, quartz feldspathic gneiss and migmatites occupy vast area of low lying portions of the study area. In general these rocks show well banded character with darker bands rich in hornblende and biotite and the lighter bands showing quartz feldspathic composition. Depending on the modal percentage of the mafic minerals the rock types vary among the three end members. The migmatite shows well differentiation between darker bands and white bands. These bands are folded into three generations of fold and interference patterns and sheath folds are observed at many localities.

The field observation indicates that the charnockites and migmatites share a transitional margin. This change is associated with gradual increase of colour from greasy nature and grey colour to pale grey colour, reduction in 
grain size from coarse to medium grain and increase in producing very long quartz ribbons. Under cross polar the the degree of foliation. Cut off patches of charnockites and recrystallization of the quartz ribbon is observed. In amphibolites are observed within the gneissic rock.

\section{Mylonite}

The Sitampundi $\sim$ Kanjamalai shear zone is marked by quartzo feldspathic mylonites derived from the mylonitisation of charnockites, quartz-Feld spathic gneisses, and hornblende-biotite phyllonites derived from the mylonitisation of the mafic granulites.The mylonites have prominent porphyroclasts (Fig. 2a, 2c, 2d), telepathic ribbons (Fig.2b).The mylonites are fine to medium grained. Quartzo feldspathic mylonites are extremely foliated and

fine grained, and contain layers of quartz ribbons alternating with mica rich layers (Fig. 2.D) The quartz grains have undergone dynamic Recrystallization majority cases the individual quartz grains are rectangular in shape mimicking the host quartz ribbon. These rectangular quartz ribbons are devoid of undulose extinction. So, this suggests that the static recrystallization has reset an earlier crystallisation related to shearing. However, in some of the sections oblique quartz grains with lensoidal geometry are observed within the quartz ribbon defining the $S \sim C$ fabric in the mylonite (Fig. 2e).

Apart from quartz ribbons the mylonites consists of feldspar clasts of $\boldsymbol{\sigma}, \boldsymbol{\delta}$ and $\boldsymbol{\varphi}$ types that represent the Remnants of original feldspar grains. The feldspar clasts are of different sizes and shape; some are marked by intragranular faults (Fig. 2f).
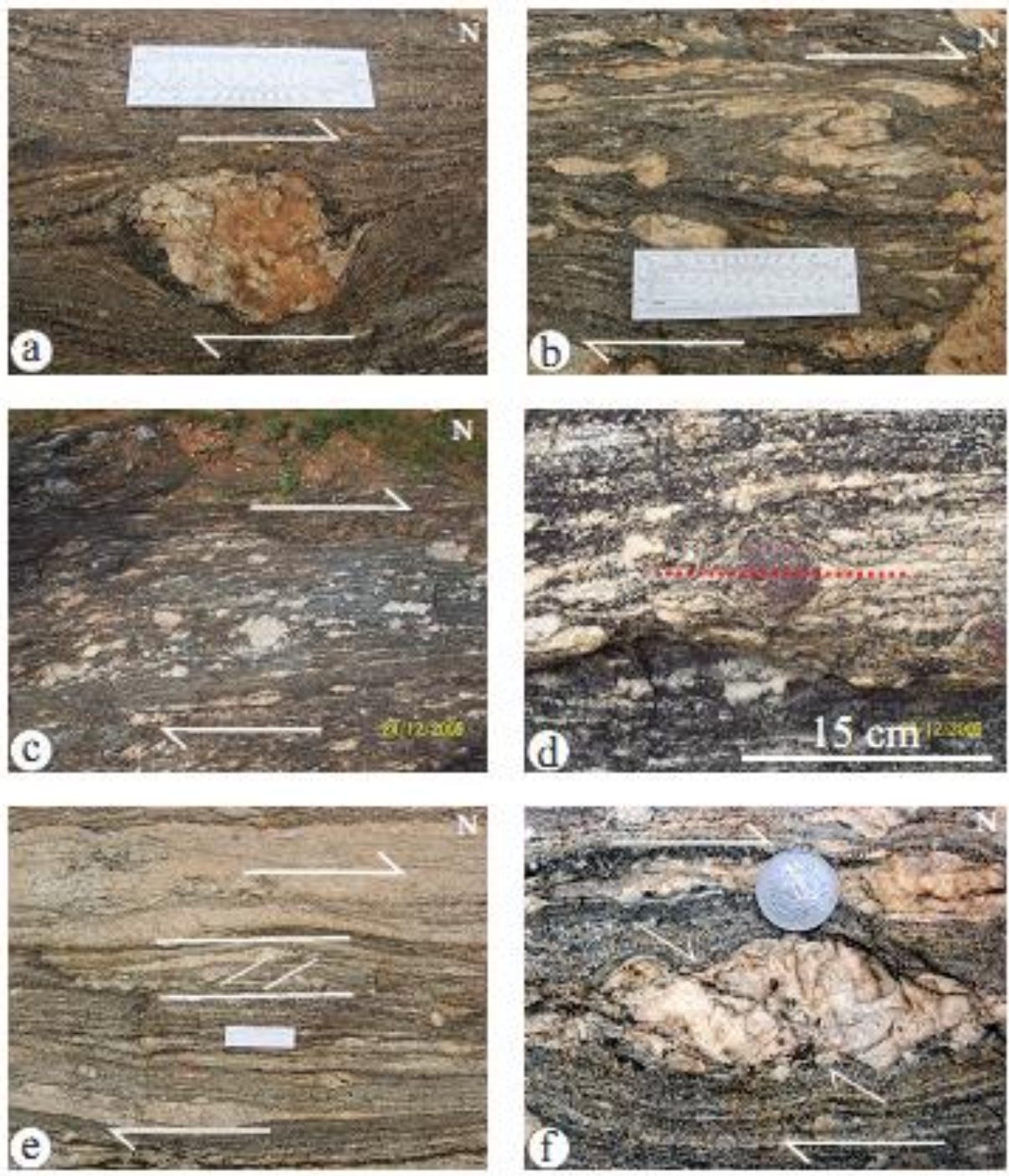

Fig 2. a) $\boldsymbol{\delta}$ Clast near Morepalayam showing dextral sense. b) Ductile-Feldspar ribbons. c) $\boldsymbol{\sigma}$ type Clast showing dextral sense. d) $\varphi$ type Garnet armed by ductile feldspars. e) S C fabric showing right lateral shear sense. f) Antithetic microfault in quartz boudin with right lateral shear

The quartz ribbons are folded around the porphyroclasts are elliptical in shape and show well porphyroclast. Quartz and mica are crystallised in the defined tails made up of feldspar grains (Fig. 2c). This pressure shadow areas. In some of the rocks the suggests that the temperature $\left(500\right.$ to $\left.600{ }^{\circ} \mathrm{C}\right)$ of shearing 
has reached up to feldspar ductile level (Fig. 2b). Back rotation is also observed in feldspar porphyroclast. The mylonite layers are folded; shear planes are developed along the limb.

Under microscope, the gneissic structure is well defined with alternate layers of hornblende, biotite rich units and the quartz Feld spathic unit. At places the rotated garnet poyphyroblast are present which shows retrogression to epidote and hornblende. The $\mathrm{S} \sim \mathrm{C}$ fabric is also observed where oblique fabric is observed to the main foliation. These features corroborate the shearing effect on the rocks (Fig. 3A). Quartz is the dominant phase with little bit of feldspar and microcline in the rock, biotite shows straight extinction and it has been recrystallized around the microscopic fold hinges, suggesting static recrystallization subsequent to deformation (Fig. 3). In general, the degree of undulose extinction in quartz as well as in feldspar is less and the grain margins are rounded suggesting the fact that the static recrystallization has taken place without the development of triple junctions and straight grain margins. Microcline is dominant in some of the rocks and the grain margins are serrated and the evidence of bulging is prominent. The plagioclase dominant variety is comparatively medium grained and shows equigranular texture. Intergrowth between $\mathrm{k}$ feldspar and plagioclase has produced myrmekitic texture and with quartz, graphic intergrowth. In the segregated spot of $\mathrm{k}$ feldspar, the biotite grains are folded around the spot suggesting late kinematic growth of the feldspar. Biotite grains show pleochroic halos due to monazite inclusions. In some of the quartz Feld spathic gneiss bandings are well developed and orthopyroxenes are present in the darker band and magnetite crystals occur in cluster.

Structure

The Sitampundi Kanjamalai shear zone, near Morepalayam hill shows the development of mylonites within the parent rock mafic granulite, migmatites and quartz feldspathic gneisses. It has a NS NNW $\sim \mathrm{SSW}$ trend near Morepalayam area in the margin of Sangakiri granite (Fig.4). The mylonites have developed in the parent rock of mafic granulite; due to shearing amphiboles are developed, thus the rock appears an amphibolite. The adjoining quartz feldspathic gneisses and migmatites have also been sheared. Sangakiri granites intrude these rock assemblages therefore the shear zone does not continue further south. Quartz and pegmatite veins are emplaced into the mylonites. The mylonitic foliations are dipping easterly at steep angle and stretching lineation is strike slip.
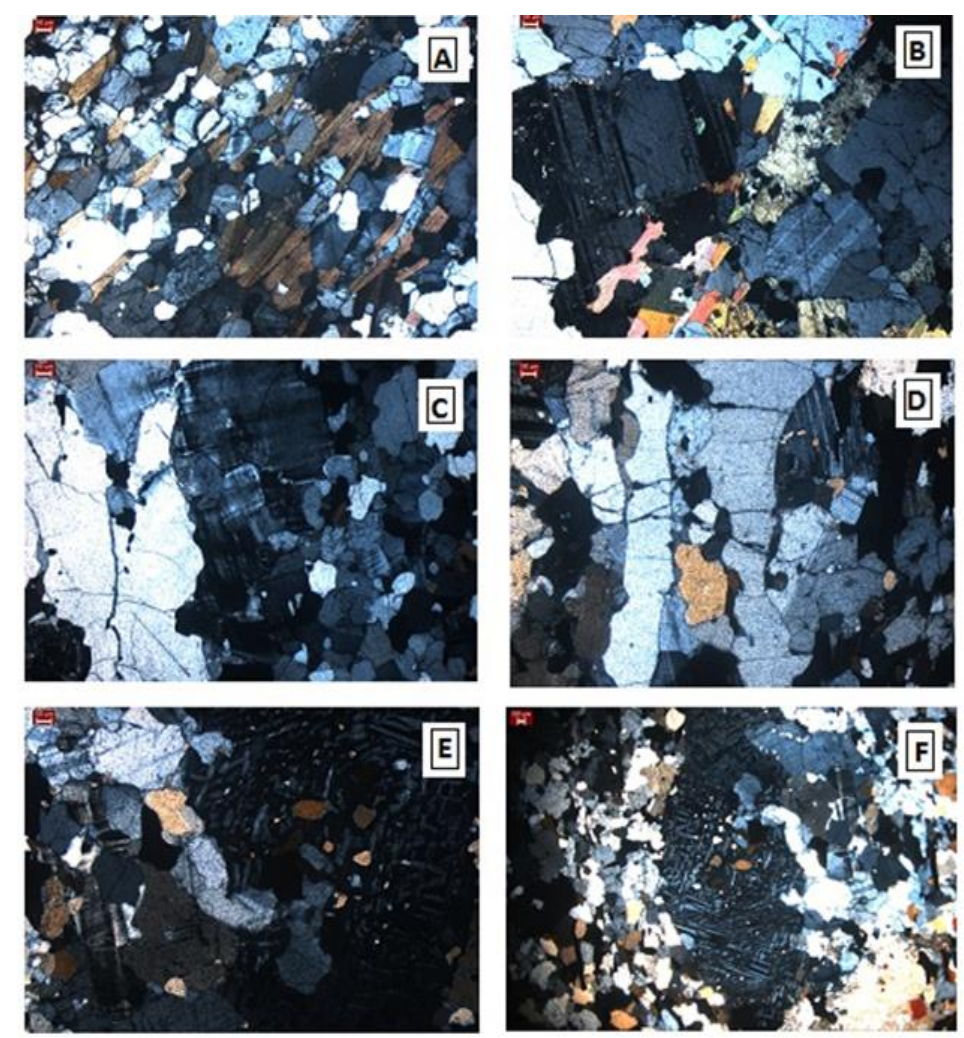

Fig 3. The photomicrographs of mylonite (A) T Section of 04 sample showing the mineral alignment along the shearing. (B) It shows the simple twinning in Feldspar grain. (C) L Section of the sample showing the chessboard twinning in Feldspar grains.(D) L Section of the sample showing elongated Quartz ribbon. (E) and (F) L Section of the MP2 Sample showing Albite Lamella in Perthite. 


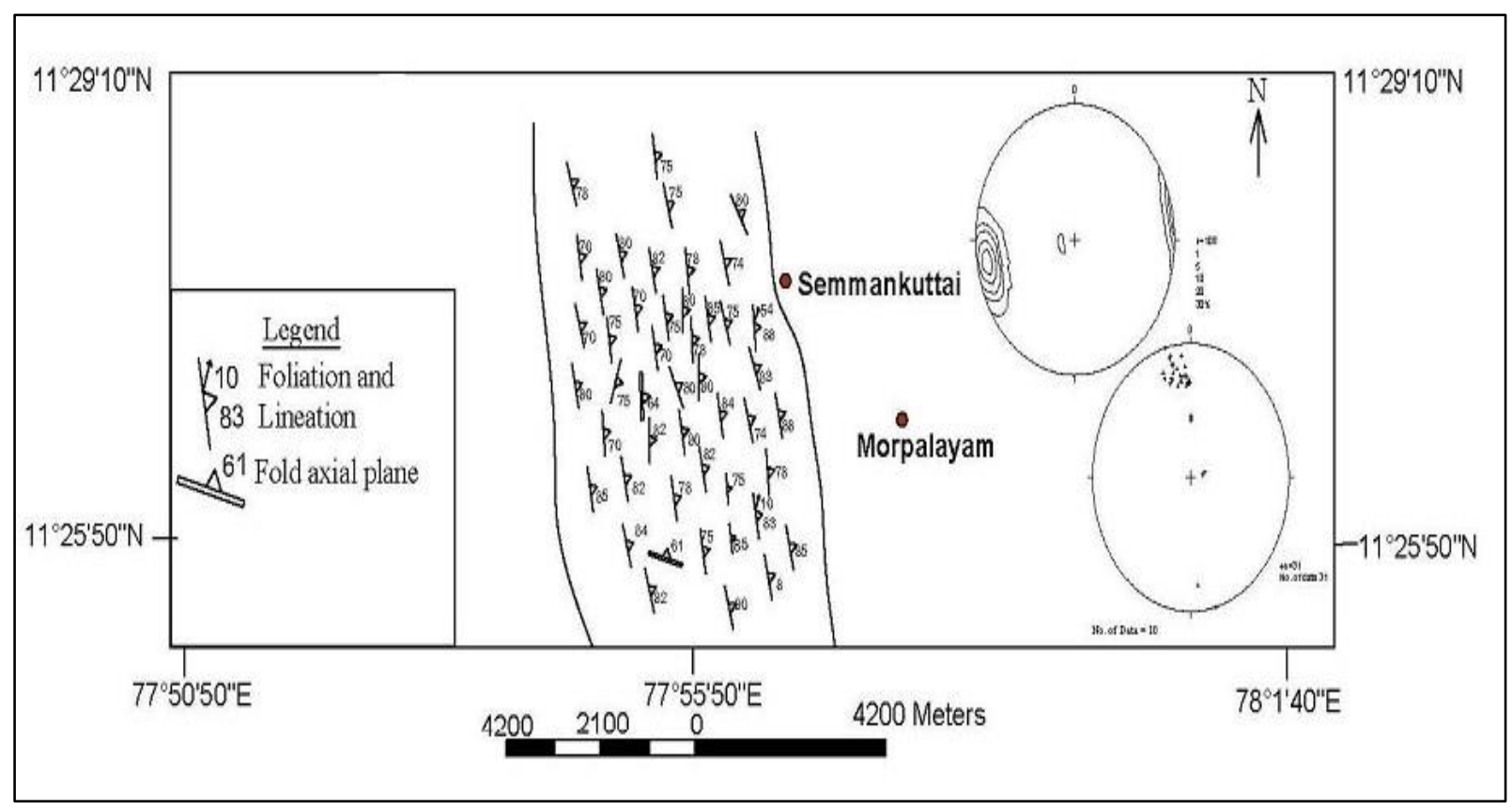

Fig 4. Structural reading of Morepalayam area.

\section{Methodology}

The whole outcrop of the shear zone profile was first studied macroscopically in detail. The aim of that macroscopic study was to identify structurally different rocks with regard to their deformational reworking. Then places for taking oriented sample were selected (Fig. 1). The samples represented are deformed as different types of brittle ductile tectonites mylonites. The mylonites in thin section are rocks with strong foliation and well marked traces of stretching lineation on the surface of the foliation planes. For the purpose of microscopic study, 10 oriented samples were collected and 7 thin sections were prepared in the planes parallel to the stretching lineation and normal to the mylonitic foliation in order to characterise microfabric, deformational reworking, as well as mineralogical and modal composition of the tectonites. Microscopic observations were made using petrographic polarising microscope. The mylonites were classified according to metamorphic grade of deformation and to their original lithotype. The microfabric of the deformed rocks was assessed using method presented by [12].

Samples within the high strain zone were selected to measure the aspect ratios of the long, intermediate, and short axes of deformed objects. The planes (XZ) for measurement are parallel to the lineations and normal to the foliations. Maximum symmetry structures and fabrics are observed in the lineation normal plane (ZY). Quartz, as main mineral in granitic mylonites, has been used as a strain marker in a number of greenschist facies high strain zone. Bailey et al., 2003 demonstrated that quartz grain shapes record strain ratios similar to fractured and badinage feldspar grains at the same deformation condition [13].

\section{Strain Analysis}

Strain analysis is a tool to understand the mode and intensity of deformation in an area to interpret the nature and regime of tectonic condition through various methods.

\section{Kinematic Indicators}

The mylonite microstructure consist of dynamically recrystallized migration type quartz as the individual grain boundary is well preserved producing quartz ribbons with rectangular grains indicating static recrystallization. The K Feldspar megacrysts are angular and are wrapped by monomineralic quartz ribbon. The porphyroclast and ribbon quartz defining the S C fabric. The cluster of feldspar and quartz ribbon together shows sinisterly sense in a dextral shear zone. This reverse shears can also be the result of switching in strain regimes within domains. This contrasting shear sense indicators can be considered as the product of partitioning of both strain and vorticity between domains $[4,14]$.

\section{Flinn Plot}

Flinn (1962) first gave an idea about the deformation path concept, which gives an idea about how strain ellipsoids change their shape and size throughout the deformation history. The basic assumption of the Flinn Plot is that the strain history remains the same for all the components but the finite strain being variable among different components. The Flinn diagram takes into account the semi major axes $\mathrm{X}, \mathrm{Y}, \mathrm{Z}$ of the strain ellipsoid. The ratio $\mathrm{X} / \mathrm{Y}$ is plotted against the ratio $\mathrm{Y} / \mathrm{Z}$. 


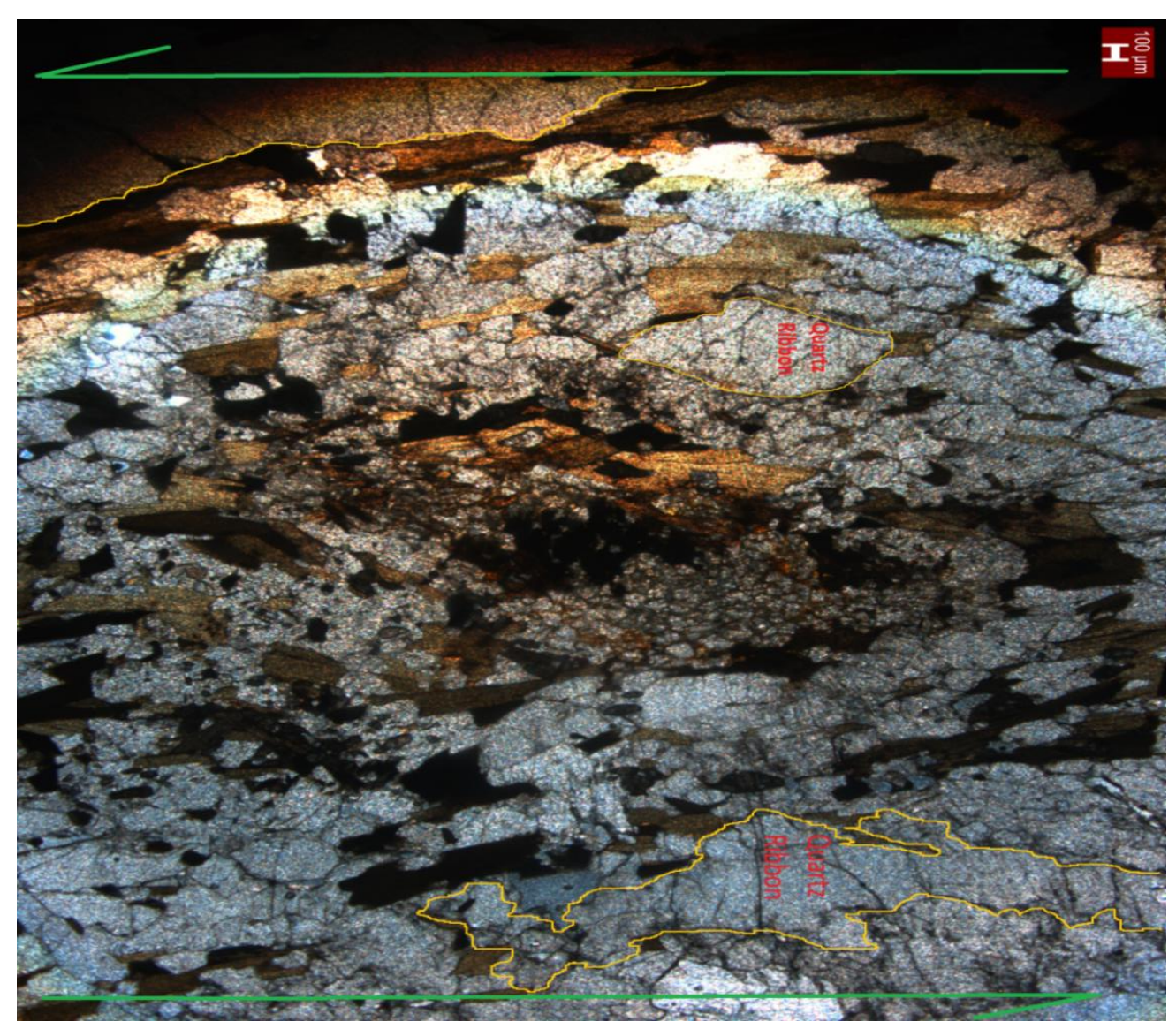

Fig 5. Quartz ribbon shows shear sense

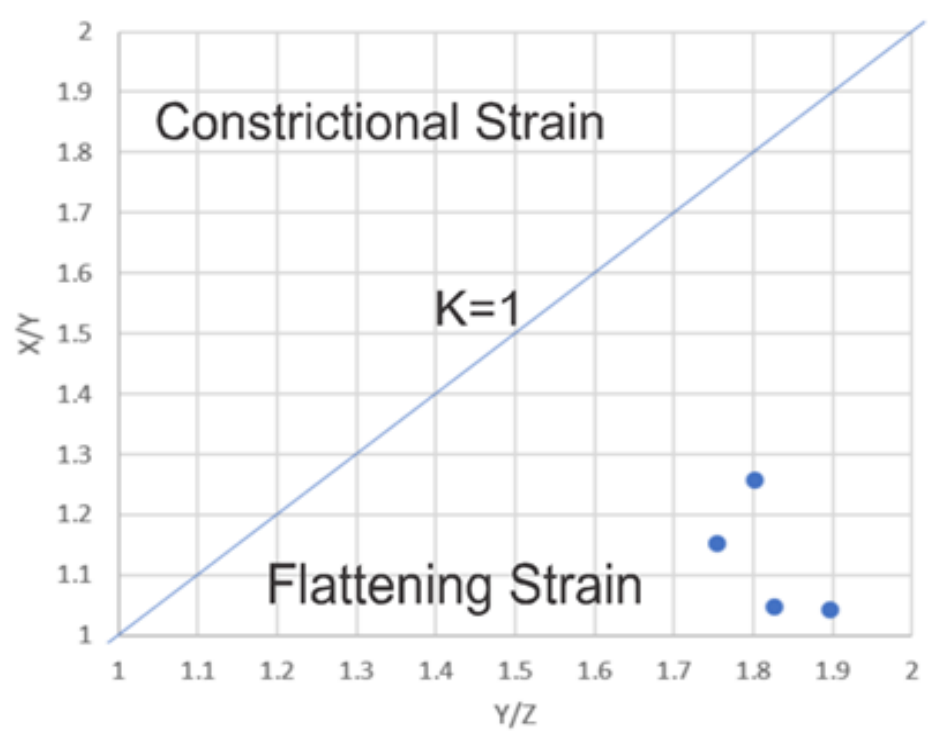

Fig .6 Flinn plot of Mylonite

If the deformation is of plane strain nature, the plot software. The value of $\mathrm{k}$ is less than 1 for the mylonite lies on a line passing through the origin of the plot making samples and thus it lies in the flattening zone [15]. an angle of $45^{\circ}$ with both the $\mathrm{X}$ and $\mathrm{Y}$ axes (Fig.5).

Vorticity and Strain Analyses

Two dimensional strains for deformed quartz grains

Three techniques for quantifying vorticity of flow have been measured on $\mathrm{X} / \mathrm{Y}$ and $\mathrm{Y} / \mathrm{Z}$ sections and plotted in have proved applicable to our samples: Method 1, the Flinn's plot (Fig.6) to know three dimensional strains porphyroclast distribution method of Wallis et al., Method 2, (Ramsay and Wood 1973) with aid of Image J and Ellipse Fit the porphyroclast hyperbolic distribution method of [16]. 
Method 3, the quartz c axis fabric and strain ratio method of Wallis et al.,. All three methods employ data collected on section planes cut perpendicular to foliation and parallel to lineation. The methods assume that the vorticity vector is oriented perpendicular to the maximum and minimum principal axes of finite strain (i.e. lies along the intermediate principal stretching rate axis during progressive flow), and that a non coaxial flow will lead to formation of fabrics with monoclinic symmetry (S. Wallis, pers. comm.). However, although the three methods do assume a minimum of monoclinic symmetry, they remain valid for general 3D strains and do not assume plane strain ( $\left.k^{1 / 4} 1\right)$ deformation conditions (D. De Paor, pers. comm.; S. Wallis, pers. comm.). As discussed above, approximate plane strain deformation conditions are indicated by the cross girdle pattern of quartz c raxis fabrics in our samples, and the orthogonal relationship between the cross girdle fabric and sample $Y$ direction (within foliation and perpendicular to lineation) also argues for monoclinic rather than triclinic flow.

\section{$\mathrm{Rxz} / \beta$ Method}

The strain ratio/quartz $c$ a axis fabric method (referred to here in after as RXZ/ $\beta$-method) is an improvement of the semi quantitative technique proposed by Platt and Behrmann (1986), and incorporates strain data measured in the XZ plane of finite strain (RXZ) with the angle $\beta$ between the flow plane (A1) and the S A foliation as determined from quartz $c$ axis fabric. Wallis et al., demonstrated that for a given pair of values $(\mathrm{RXZ} / \beta)$, the Wm can be estimated either by constructing the Mohr - circle for finite deformation in stretch space or by using the following analytical solutions:

$$
\begin{gathered}
\emptyset=\tan ^{-1} \int \frac{\sin 2 \beta}{\left[\left(R_{X Z}+1\right) /\left(R_{X Z}-1\right)\right]-\cos 2 \beta} \\
W_{m}=\sin \emptyset \frac{R_{X Z}+1}{R_{X Z}-1}
\end{gathered}
$$

Aggregates of quartz grains when dynamically recrystallized often exhibit oblique grain shape fabric, which is basically the obliquity maintained by the long axis of the grains with respect to the $S$ foliations of shearing observed on the XZ plane of deformation. Thus the angle $\delta$ is defined as the angle between the long axis of the oblique quartz grains and the $S$ foliations. Mean kinematic vorticity value $(\mathrm{Wm})$ has been obtained by Rxz / $\beta$ method for the shear zone [17]. The following plot shows the finite strain ratio Rxz versus angle $\beta$ (or $\Theta$ ) and gives the value of $\mathrm{Wm}$ which is of 0.36. (Fig.7).

\section{Rigid Grain Graph}

For plane strain deformation, components of pure shear and simple shear can be quantified in terms of the kinematic vorticity number Wk [18].

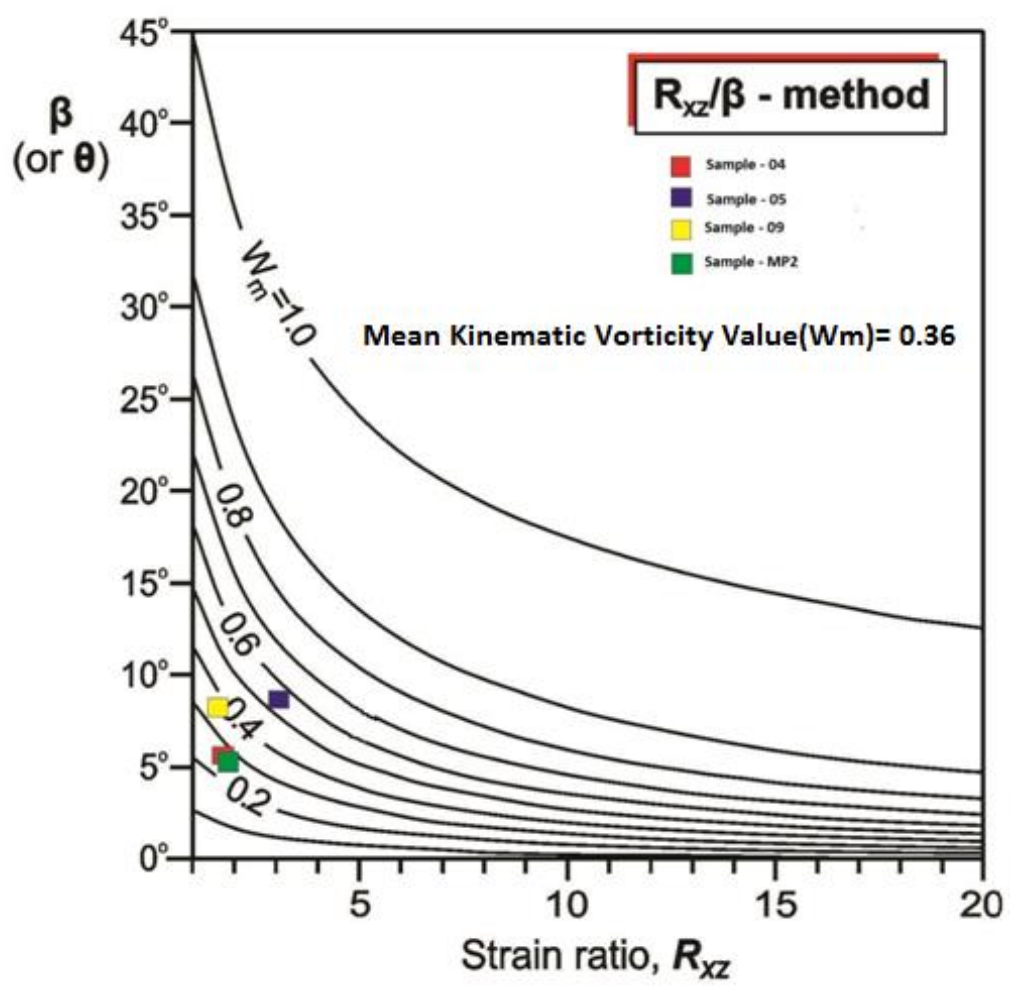

Fig 7. Mena kinematic vorticity value 

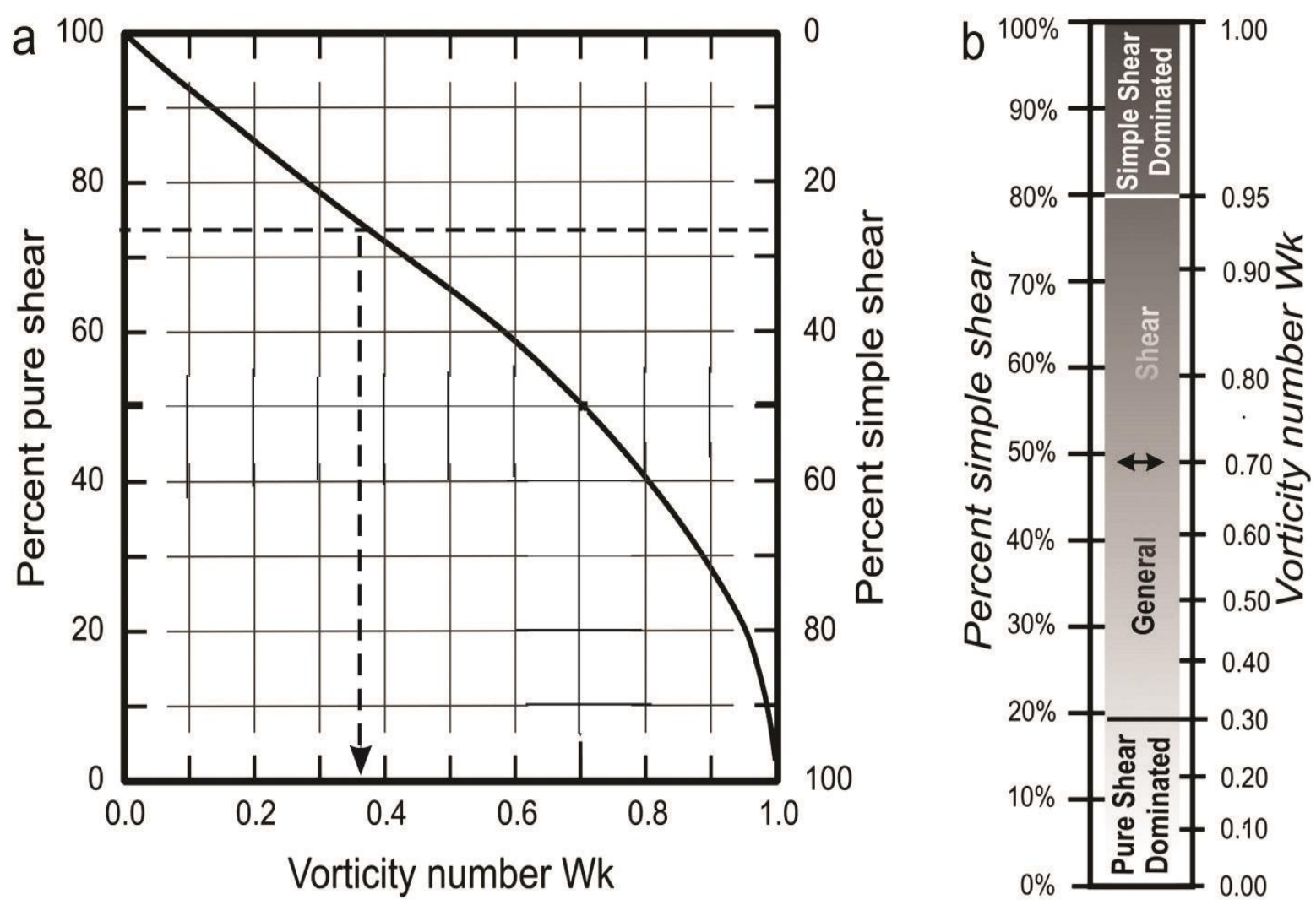

Fig 8. Pure shear Vs simple shear

Care must be taken, however, in interpreting estimated vorticity numbers (Wk) in terms of the relative contributions of pure and simple shear deformation. This is because $\mathrm{Wk}$ is defined (for $0 \leq W \mathrm{k} \leq 1$ ) as the non linear ratio of pure shear $(\mathrm{Wk}=0)$ and simple shear $(\mathrm{Wk}=1)$ components of deformation, assuming a steady state deformation (Means 1994). Fig.8 The plot shows the Wk versus \% of pure and simple shear. The graph indicates that the mylonite has $74 \%$ pure shear component and $26 \%$ simple shear component.

\section{Discussion}

1. In SKSZ near Morepalyam mylonites have been well developed and the Sankagri granite emplacement completely dismembers the exposure along the southern end.

2. The rectangular quartz ribbon devoid of undulose extinction indicates migration type recrystallization which reset earlier crystallisation related to shearing and the rotated garnet poyphyroblast shows evidence for retrogression process.

3. The quartz ribbon around cluster of feldspar together shows left lateral shear sense at some place. The meso as well as microstructures with apparent reverse shear sense, restricted to high strain domain can also be considered as consistent with the regional dextral kinematics (after R.Satheesh Kumar, V.Prasanna Kumar et al.,) [19]
4. The $\sigma, \delta$ and $\varphi$ type feldspar clast, back rotation, intergranular faults in feldspar, are indicating a dextral sense with strike slip component marked by horizontal lineations.

5. The ductile shearing of feldspars are marked by folding of feldspar ribbons and well defined feldspar tail suggesting high temperature shearing of above $700^{\circ} \mathrm{C}$.

6. In the segregated spot of $\mathrm{k}$ feldspar, the biotite grains are folded around the spot suggesting late kinematic growth of the feldspar. Biotite grains shows pleochroic halos due to monazite inclusions.

\section{Conclusion}

The kinematic indicators such as S C fabric and the quartz ribbon around feldspar shows dextral shear sense. The strain analysis of the mylonite indicates flattening type of strain and the kinematic vorticity value $\mathrm{Wm}$ is of value 0.36 which indicates the general shear with large component of pure shear transgression. Further the shear zone exhibit monoclinic symmetry along the shear plane and ductile feldspar. Hence the Sittampundi kanjamalai shear zone at certain places has experienced high temperature (above $700^{\circ} \mathrm{C}$ ) shearing corresponds to deeper crust and then exhumed.

\section{References}

[1] R.H. Sibson, Fault rocks and fault mechanisms, J. Geol. Soc., 133 (1977) 191 213. 
[2] R. A. J. Trouw, C.W. Passchier, D.J. Wtersma, Atlas of Mylonites and related microstructures, Springer Verlag Berlin Heidelberg, (2009)

[3] Lister, Snoke, S C Mylonite, J Struct Geol, 6 (1984) 617 638.

[4] David C Greene, Richard A Schweickert, The Gem Lake shear zone: Cretaceous dextral transpression in the northern Ritter Range pendant, eastern Sierra Nevada, California, Tectonics. 14 (1995) 945 961.

[5] T.H. Bell, M.A. Etheridge, Microstructure of mylonites and their descriptive terminology, Lithos. 6 (1973) 337 348.

[6] N. B. W. Harris, M. Santosh, P. N. Talor, Crustal evolution in south India: Constraints from $\mathrm{Nd}$ isotopes, J. Geol, 102 (1994) 139 150.

[7] Joy Gopal Ghosh, Maarten J. de Wit, and R. E. Zartman, Age and tectonic evolution of Neoproterozoic ductile shear zones in the Southern Granulite Terrain of India, with implications for Gondwana studies, Tectonics. 23 (2004) 1 38.

[8] K.Naha, R.Srinivasan, Nature of the Moyar and Bhavani shear zones, with a note on its implication on the tectonics of the southern Indian Precambrian shield, Proceedings of the Indian Academy of Sciences Earth and Planetary Sciences, (1996).

[9] S.A. Drury, N.B.W. Harris, R.W. Holt, G.J. Reeves $\sim$ Smith, R.T. Wightman, Precambrian tectonics and crustal evolution in South India, J. Geol, 92 (1984) 3 20.

[10]K.S. Valdiya, Late Quaternary movement and landscape rejuvenation in SE Karnataka and adjoining TN in south Indian shield, Jour. Geol. Soc. India, 51 (1998) 139 166.

[11]T. Yellappa, M. Santosh, T.R.K. Chetty, S. Kwon, C. Park, P. Nagesh, D.P. Mohanty, V. Venkatasivappa, A Neoarchean dismembered ophiolite complex from southern India: geochemical and geochronological constraints on its suprasubduction origin, Gondwana. Res, 21 (2012) 246 265.

[12]C.W. Passchier, R.A.J. Trouw, (1996) Micro tectonics, Springer Verlag, Berlin, Germany,

[13]C.M. Bailey, E.L. Eyster, General shear deformation in the Pinaleño Mountains metamorphic core complex, Arizona, J. Struct. Geo., 25 (2003) 1883 1892.

[14]J. F. Hippertt, F.D.Hongn, Deformation mechanisms in the mylonite/ultramylonite transition, J. Struct. Geo., 20 (1998) 1435 1448.

[15]J.G. Ramsay, D. S. Wood, The geometric effects of volume change during deformation processes, Tectonophys. 13 (1973) 263 277.
[16] C.M. Bailey, C. Simpson, D.G. De Paor, Volume loss and tectonic flattening strain in granitic mylonites from the Blue Ridge province, central Appalachians, J. of Struct. Geo. 16 (1993) 1403 1416.

[17]P. Xypolias, Vorticity analysis in shear zones: A review of methods and applications, J. Struct. Geo. 32 (2010) 2072 2092.

[18] W.D. Means, B.E. Hobbs, G.S. Lister, P.F. Williams, Vorticity and non coaxialityinprogressive deformation, J. Struct. Geol, 2 (1980) 371 378.

[19]R.Satheesh Kumar, V.Prasannakumar, Fabric Evolution in Salem - Attur Shear Zone, South India and its Implications on the kinematics, Gondwana Res. 16 (2009) 37 44.

\section{About The License}

(C) 2019 The Authors. This work is licensed under a Creative Commons Attribution 4.0 International License which permits unrestricted use, provided the original author and source are credited. 